\title{
Differential coexpression network modules observed in human hepatocellular carcinoma progression
}

\author{
Hui Yu', Zhongming Zhao ${ }^{1,2,3^{*}}$ \\ From 12th Annual UT-ORNL-KBRIN Bioinformatics Summit 2013 \\ Buchanan, TN, USA. 22-24 March 2013
}

\section{Background}

While an understanding of the human interactome is within attainable reach [1], an impending challenge is to uncover the condition-specific dynamics of the proteinprotein interaction (PPI) network, especially those that coordinate with disease progression [2]. Differential coexpression analysis (DCA) $[3,4]$ has recently emerged as an effective approach to address this issue, but such an effort has yet to be thoroughly tested.

\section{Materials and methods}

In this work, we explored the validity of extracting contextspecific PPI subnetworks by analyzing the differential coexpression of interacting protein pairs. We first compared highly differentially coexpressed genes ("high-DC genes") with highly differentially expressed genes ("high-DE genes") in terms of their fit within a PPI-network analysis. Then, in a human PPI network overlaid with gene-gene differential correlation (DC) values calculated from the microarray gene expression dataset GSE6764, we sought high-DC subnetworks for each disease stage transition of hepatocellular carcinoma (HCC).

\section{Results}

The validity of integrating DCA with a PPI network was demonstrated in two lines of evidence. First, higher expression correlations were associated with PPI pairs than nonPPI pairs, and exceptionally high DC values were observed within part of the PPI pairs. Second, compared with the high-DE genes, high-DC genes were more enriched with HCC-related genes and were more condensed in the

\footnotetext{
* Correspondence: zhongming.zhao@vanderbilt.edu

'Department of Biomedical Informatics, Vanderbilt University School of Medicine, Nashville, TN 37203, USA

Full list of author information is available at the end of the article
}

reference network. Then, we extracted DC-PPI subnetworks for the four transitions over five HCC stages. All subnetworks turned out to be significantly enriched with HCC-related genes, HCV-targeted genes, and cancer genes. A comparison of the multiple transition-wise subnetworks gene by gene enabled us to identify the recurrent hub proteins, while comparing them edge by edge allowed us to identify protein pairs with constantly-changing relationships.

\section{Conclusions}

We demonstrated a differential coexpression workflow within the context of a human PPI reference network. As applied to a multi-stage HCC expression dataset, our approach has generated a set of differentially coexpressed genes and network modules with promising candidates for follow-up HCC investigation.

\section{Acknowledgements}

This work was partially supported by grants R01LM011177, P50CA095103, and the VICC Cancer Center Core grant P30CA68485 from the National Institutes of Health $(\mathrm{NIH})$.

\section{Authors' details}

'Department of Biomedical Informatics, Vanderbilt University School of Medicine, Nashville, TN 37203, USA. 'Department of Psychiatry, Vanderbilt University School of Medicine, Nashville, TN 37232, USA. ${ }^{3}$ Department of Cancer Biology, Vanderbilt University Medical Center, Nashville, TN 37232, USA.

\section{Published: 22 October 2013}

\section{References}

1. De Las Rivas J, Fontanillo C: Protein-protein interaction networks: unraveling the wiring of molecular machines within the cell. Briefings in Functional Genomics 2012, 11(6):489-496.

2. Przytycka TM, Singh M, Slonim DK: Toward the dynamic interactome: it's about time. Briefings in Bioinformatics 2010, 11(1):15-29.

\section{Ciomed Central}


3. Yu H, Liu BH, Ye ZQ, Li C, Li YX, Li YY: Link-based quantitative methods to identify differentially coexpressed genes and gene pairs. BMC Bioinformatics 2011, 12:315.

4. de la Fuente A: From 'differential expression' to 'differential networking' identification of dysfunctional regulatory networks in diseases. Trends in Genetics: TIG 2010, 26(7):326-333.

doi:10.1186/1471-2105-14-S17-A11

Cite this article as: $Y u$ and Zhao: Differential coexpression network modules observed in human hepatocellular carcinoma progression. BMC Bioinformatics 2013 14(Suppl 17):A11.

Submit your next manuscript to BioMed Central and take full advantage of:

- Convenient online submission

- Thorough peer review

- No space constraints or color figure charges

- Immediate publication on acceptance

- Inclusion in PubMed, CAS, Scopus and Google Scholar

- Research which is freely available for redistribution

Submit your manuscript at www.biomedcentral.com/submit
C Biomed Central 